\title{
Modeling the Process of Producing Hydrogen from Methane
}

\author{
A. M. Dubinin, V. G. Tuponogov*, and I. S. Ikonnikov \\ Ural Federal University, ul. Mira 19, Yekaterinburg, 620002 Russia \\ *e-mail:v.g.tuponogov@ustu.ru \\ Received February 7, 2013
}

\begin{abstract}
Using the chemical reactions that accompany the production of syngas via the steam reforming of methane as a basis, the differential material balance equations were derived and solved for all conversion products on an aluminum/nickel catalyst. For the following stage of hydrogen synthesis on an iron/chromium catalyst, the system of two differential equations of the material balance of the direct and reverse reactions of steam carbon monoxide conversion was obtained and solved. The analytical solutions were compared with the experiment.
\end{abstract}

DOI: $10.1134 / \mathrm{S} 0040579513050163$

\section{INTRODUCTION}

Hydrogen is used to produce ammonia, fertilizers, and fuels for internal combustion engines, as well as for the direct hydrogenation of coals and the reduction of metallic ores.

In the given work, the process of steam methane reforming characterized by lower fuel consumption compared to the steam oxygen process $[1,2]$ is modeled at the stage of syngas production. The steam reforming process is considered for the ratio $\mathrm{H}_{2} \mathrm{O}$ : $\mathrm{CH}_{4}=2: 1$, in contrast to [3,4], where the given process is considered at a ratio $\mathrm{H}_{2} \mathrm{O}: \mathrm{CH}_{4}=1: 1$.

The steam reforming of methane on the aluminum/nickel catalyst at a ratio $\mathrm{H}_{2} \mathrm{O}: \mathrm{CH}_{4}=2: 1$ can be represented by the endothermic reaction

$$
2 \mathrm{H}_{2} \mathrm{O}+\mathrm{CH}_{4} \stackrel{K_{1}}{\longrightarrow} \mathrm{H}_{2} \mathrm{O}+\mathrm{CO}+3 \mathrm{H}_{2},
$$

which is accompanies by a 1.66-fold increase (by $5 / 3$ times) in the volume of products and the steam conversion of $\mathrm{CO}$ according to the direct reaction

$$
\mathrm{H}_{2} \mathrm{O}+\mathrm{CO}+3 \mathrm{H}_{2} \stackrel{K_{2}}{\longrightarrow} \mathrm{CO}_{2}+4 \mathrm{H}_{2}
$$

and the reverse reaction [5]

$$
\mathrm{CO}_{2}+4 \mathrm{H}_{2} \stackrel{K_{3}}{\longrightarrow} \mathrm{H}_{2} \mathrm{O}+\mathrm{CO}+3 \mathrm{H}_{2} \text {. }
$$

For this reason, the products of reaction (1) (syngas) always contain carbon dioxide in small amounts (from 10 to 3 vol \% depending the process temperature).

The syngas then enters the second reactor, where reactions (2) and (3) proceed on an iron/chromium catalyst, but are characterized by the other rate constants $K_{2}^{*}$ and $K_{3}^{*}$. The final stage in the modeling of the production of hydrogen is the separation of hydrogen and carbon dioxide in an absorber.

\section{MODELING THE STEAM METHANE REFORMING PROCESS}

A steam-methane mixture is fed into the reactor vertical retort's bottom section filled with a finegrained catalyst. Reactions (1)-(3) proceed on the surface of the catalyst to form the conversion products, the velocity of which is increased with decreasing methane concentration and described by the dependence $w_{z}=w_{0} /\left(1+2 r_{\mathrm{CH}_{4}}\right)$, where $w_{0}$ is the velocity of end reforming products (at the retort outlet) on an empty cross section basis at operational pressure and temperature.

The equation that describes the decrease in methane concentration along the reactor height $z$ is written as follows:

$$
\frac{w}{\varepsilon} \frac{d r_{\mathrm{CH}_{4}}}{d z}=-K_{1} S r_{\mathrm{CH}_{4}} .
$$

The solution of Eq. (4) with the boundary condition

has the form

$$
\left.r_{\mathrm{CH}_{4}}\right|_{z=0}=1 / 3
$$

$$
r_{\mathrm{CH}_{4}}=\frac{1}{5 \exp \left(\frac{K_{1} S \varepsilon z}{w_{0}}\right)-2} \simeq 0.2 \exp \left(-\frac{K_{1} S \varepsilon}{w} z\right) .
$$

In the latter expression, the velocity is average over the reactor height, i.e., $w=-3 w_{0} \int_{1 / 3}^{0} \frac{d r_{\mathrm{CH}_{4}}}{1+2 r_{\mathrm{CH}_{4}}}=0.766 w_{0}$.

Since only $1 \mathrm{~mol} \mathrm{H}_{2} \mathrm{O}$ reacts with $1 \mathrm{~mol}$ of $\mathrm{CH}_{4}$ by reaction (1), the residual steam in the amount $0.2 \exp \left(-\frac{K_{1} S \varepsilon}{w} z\right)$, reacts with CO by reaction (2) at a rate $0.2 K_{2} S \exp \left(-\frac{K_{1} S \varepsilon}{w} z\right)$ to form $\mathrm{CO}_{2}$. In turn, $\mathrm{CO}_{2}$ reacts with $\mathrm{H}_{2}$ by reaction (3) at a rate $K_{3} S_{\mathrm{CO}_{2}}$ to give 
Table 1. Comparison of steam methane reforming product concentrations that were obtained experimentally $\left(\mathrm{H}_{2} \mathrm{O}: \mathrm{CH}_{4}=2: 1\right)$ and calculated by the model at $T=$ $710^{\circ} \mathrm{C}$

\begin{tabular}{l|l|l|l|l|l|l}
\hline \multirow{2}{*}{ Comparison } & \multicolumn{5}{|c}{ Concentration of components } \\
& $\mathrm{CO}$ & $\mathrm{H}_{2} \mathrm{O}$ & $\mathrm{CH}_{4}$ & $\mathrm{CO}_{2}$ & $\mathrm{H}_{2}$ & $\sum r_{i}, \%$ \\
\cline { 2 - 7 } & 12.3 & 28.3 & 3.95 & 4.75 & 55.2 & 100 \\
Experiment & 14.28 & 23.19 & 4.5 & 2.7 & 55.33 & 100 \\
\hline
\end{tabular}

CO. Hence, the $\mathrm{CO}_{2}$ material balance will be written as

$$
\frac{w}{\varepsilon} \frac{d r_{\mathrm{CO}_{2}}}{d z}=0.2 K_{2} S \exp \left(-\frac{K_{1} S \varepsilon}{w} z\right)-K_{3} S r_{\mathrm{CO}_{2}} .
$$

The solution of Eq. (7) with the boundary condition

has the form

$$
\left.r_{\mathrm{CO}_{2}}\right|_{z=0}=0
$$

$$
\begin{gathered}
r_{\mathrm{CO}_{2}}=0.2 \frac{K_{2}}{K_{1}-K_{3}} \\
\times\left[\exp \left(-\frac{K_{3} S \varepsilon}{w} z\right)-\exp \left(-\frac{K_{1} S \varepsilon}{w} z\right)\right] .
\end{gathered}
$$

Carbon monoxide that is formed by reaction (1) at rate $0.2 K_{1} \exp \left(-\frac{K_{1} S \varepsilon}{w} z\right)$, reacts with $\mathrm{H}_{2} \mathrm{O}$ by reaction (2) at rate $0.2 K_{2} \exp \left(-\frac{K_{1} S \varepsilon}{w} z\right)$ to produce $\mathrm{CO}_{2}$. In reaction (3), $\mathrm{CO}_{2}$ reacts with $\mathrm{H}_{2}$ again at a rate $\mathrm{K}_{3} \mathrm{Sr}_{\mathrm{CO}_{2}}$ and converts into carbon monoxide. For this reason, the mass balance equation for $\mathrm{CO}$ can be written as

$$
\begin{gathered}
\frac{w}{\varepsilon} \frac{d r_{\mathrm{CO}}}{d z}=0.2 K_{1} S \exp \left(-\frac{K_{1} S \varepsilon}{w} z\right) \\
-0.2 K_{2} S \exp \left(-\frac{K_{1} S \varepsilon}{w} z\right)+K_{3} S r_{\mathrm{CO}_{2}} .
\end{gathered}
$$

At the boundary condition

$$
\left.r_{\mathrm{CO}}\right|_{z=0}=0
$$

the solution of Eq. (10) has the form

$$
\begin{aligned}
r_{\mathrm{CO}}= & 0.2\left\{\frac{K_{1}-K_{2}-K_{3}}{K_{1}-K_{3}}\left[1-\exp \left(-\frac{K_{1} S \varepsilon}{w} z\right)\right]\right. \\
& \left.+\frac{K_{2}+K_{3}}{K_{1}-K_{3}}\left[1-\exp \left(-\frac{K_{3} S \varepsilon}{w} z\right)\right]\right\} .
\end{aligned}
$$

Steam is spent at a rate $K_{1} S\left(r_{\mathrm{H}_{2} \mathrm{O}}-0.2\right)$ in reaction (1) with $\mathrm{CH}_{4}$, and $\mathrm{H}_{2} \mathrm{O}$ is spent at a rate $0.2 K_{2} S \exp \left(-\frac{K_{1} S \varepsilon}{w} z\right)$ in reaction (2) with CO. Steam is formed by reaction (3) from $\mathrm{CO}_{2}$ and $\mathrm{H}_{2}$ at a rate
$K_{3} S r_{\mathrm{CO}_{2}}$. As a result, we obtain the following steam mass balance equation:

$$
\begin{gathered}
\frac{w}{\varepsilon} \frac{d r_{\mathrm{H}_{2} \mathrm{O}}}{d z}=-K_{1} S\left(r_{\mathrm{H}_{2} \mathrm{O}}-0.2\right) \\
-0.2 K_{2} S \exp \left(-\frac{K_{1} S \varepsilon}{w} z\right)+K_{3} S r_{\mathrm{CO}_{2}} .
\end{gathered}
$$

The solution of Eq. (13) with the boundary condition

$$
\left.r_{\mathrm{H}_{2} \mathrm{O}}\right|_{z=0}=\frac{2}{3}
$$

with consideration for Eq. (9) has the form

$$
\begin{gathered}
r_{\mathrm{H}_{2} \mathrm{O}}=0.2+0.46\left\{\exp \left(-\frac{K_{1} S \varepsilon}{w} z\right)\right. \\
-\frac{S \varepsilon}{w} \frac{K_{1} K_{2}}{K_{1}-K_{3}} z \exp \left(-\frac{K_{1} S \varepsilon}{w} z\right)
\end{gathered}
$$

$$
\left.+\frac{K_{2} K_{3}}{\left(K_{1}-K_{3}\right)^{2}}\left[\exp \left(-\frac{K_{3} S \varepsilon}{w} z\right)-\exp \left(-\frac{K_{1} S \varepsilon}{w} z\right)\right]\right\} \text {. }
$$

The $\mathrm{H}_{2}$ concentration is found from the assumption that $1 \mathrm{~m}^{3}$ of steam gives $1 \mathrm{~m}^{3} \mathrm{H}_{2}$, and $1 \mathrm{~m}^{3}$ of $\mathrm{CH}_{4}$ gives $2 \mathrm{~m}^{3}$ of $\mathrm{H}_{2}$, i.e.,

$$
r_{\mathrm{H}_{2}}=0.6-1.3\left(r_{\mathrm{H}_{2} \mathrm{O}}-0.2\right)-0.5 r_{\mathrm{CH}_{4}} .
$$

The sum of component volumetric fractions is equal to 1 .

Let us derive the mass balance equations for reactions (2) and (3), which take place in the second reactor on an iron/chromium catalyst.

Carbon monoxide is spent in reaction (2) with $\mathrm{H}_{2} \mathrm{O}$ at a rate $K_{2}^{*} S r_{\mathrm{CO}}$ to form $\mathrm{CO}_{2}$, which converts into $\mathrm{CO}$ again in reaction (3) with $\mathrm{H}_{2}$ at a rate $K_{3}^{*} S r_{\mathrm{CO}_{2}}$.

The material balance equation for $\mathrm{CO}$ has the form

$$
\frac{w}{\varepsilon} \frac{d r_{\mathrm{CO}}}{d z}=-K_{2}^{*} S r_{\mathrm{CO}}+K_{3}^{*} S r_{\mathrm{CO}_{2}} \text {. }
$$

In reaction (2), $\mathrm{CO}_{2}$ is formed from $\mathrm{CO}$ and $\mathrm{H}_{2} \mathrm{O}$ at a rate $K_{2}^{*} S r_{\mathrm{CO}}$, and spent in reaction (3) with $\mathrm{H}_{2}$ at a rate $K_{3}^{*} \mathrm{Sr}_{\mathrm{CO}_{2}}$.

The material balance equation for $\mathrm{CO}_{2}$ can be written as

$$
\frac{w}{\varepsilon} \frac{d r_{\mathrm{CO}_{2}}}{d z}=S K_{2}^{*} r_{\mathrm{CO}}-S K_{3}^{*} r_{\mathrm{CO}_{2}} \text {. }
$$

The boundary conditions for Eqs. (17) and (18) are

$$
\left.r_{\mathrm{CO}}\right|_{Z=0}=0.2,\left.\quad r_{\mathrm{CO}_{2}}\right|_{Z=0}=0 .
$$

The solution of the system of Eqs. (17) and (18) with boundary conditions (19) can be expressed as

$$
r_{\mathrm{CO}_{2}}=0.2 \frac{K_{e q}}{K_{e q}+1}\left[1-\exp \left(-\frac{S \varepsilon K_{2}^{*}\left(K_{e q}+1\right) z}{K_{e q} w}\right)\right] \text {. }
$$

The outlet concentration of carbon dioxide is

$$
r_{\mathrm{CO}}=0.2-r_{\mathrm{CO}_{2}} \text {. }
$$


The steam concentration is

$$
r_{\mathrm{H}_{2} \mathrm{O}}=r_{\mathrm{CO}}
$$

and the hydrogen concentration is found from the balance equation

$$
r_{\mathrm{H}_{2}}=1-\left(r_{\mathrm{H}_{2} \mathrm{O}}+r_{\mathrm{CO}}+r_{\mathrm{CO}_{2}}\right)
$$

The above-written set of Eqs. (1)-(16) allows us to calculate the composition of syngas obtained by the steam reforming of methane at $\mathrm{H}_{2} \mathrm{O}: \mathrm{CH}_{4}=2: 1$ in the reactor with an aluminum/nickel catalyst (see calculation in Table 1), and Eqs. (20)-(23) enable the calculation of the composition of steam $\mathrm{CO}$ conversion products obtained from syngas in the reactor with an iron/chromium catalyst (see calculation in Table 2).

\section{EXPERIMENTAL}

To verify the calculation model, we performed steam methane reforming experiments at a ratio $\mathrm{H}_{2} \mathrm{O}$ :
Table 2. Comparison of experimentally obtained concentrations of conversion products of steam carbon monoxide [8] calculated by the model at $T=350^{\circ} \mathrm{C}$

\begin{tabular}{l|l|c|c|c}
\hline \multirow{2}{*}{ Comparison } & \multicolumn{4}{|c}{$\begin{array}{c}\text { Concentration of components } \\
\text { in conversion products, vol \% }\end{array}$} \\
\cline { 2 - 5 } & $\mathrm{H}_{2} \mathrm{O}$ & $\mathrm{CO}_{2}$ & $\mathrm{CO}$ & $\mathrm{H}_{2}$ \\
\hline Experiment & 4 & 16 & 4 & 76 \\
Calculation & 3.58 & 18 & 3.58 & 74.84 \\
\hline
\end{tabular}

$\mathrm{CH}_{4}=2: 1$ in an EN-60G endothermic generator with a gas-heated retort and heat recuperation (see figure). A bed of the KSN-2 aluminum/nickel catalyst with a specific outer surface area $S=258 \mathrm{~m}^{2} / \mathrm{m}^{3}$, a porosity $\varepsilon=0.345$, and a height of $1 \mathrm{~m}$ was poured into

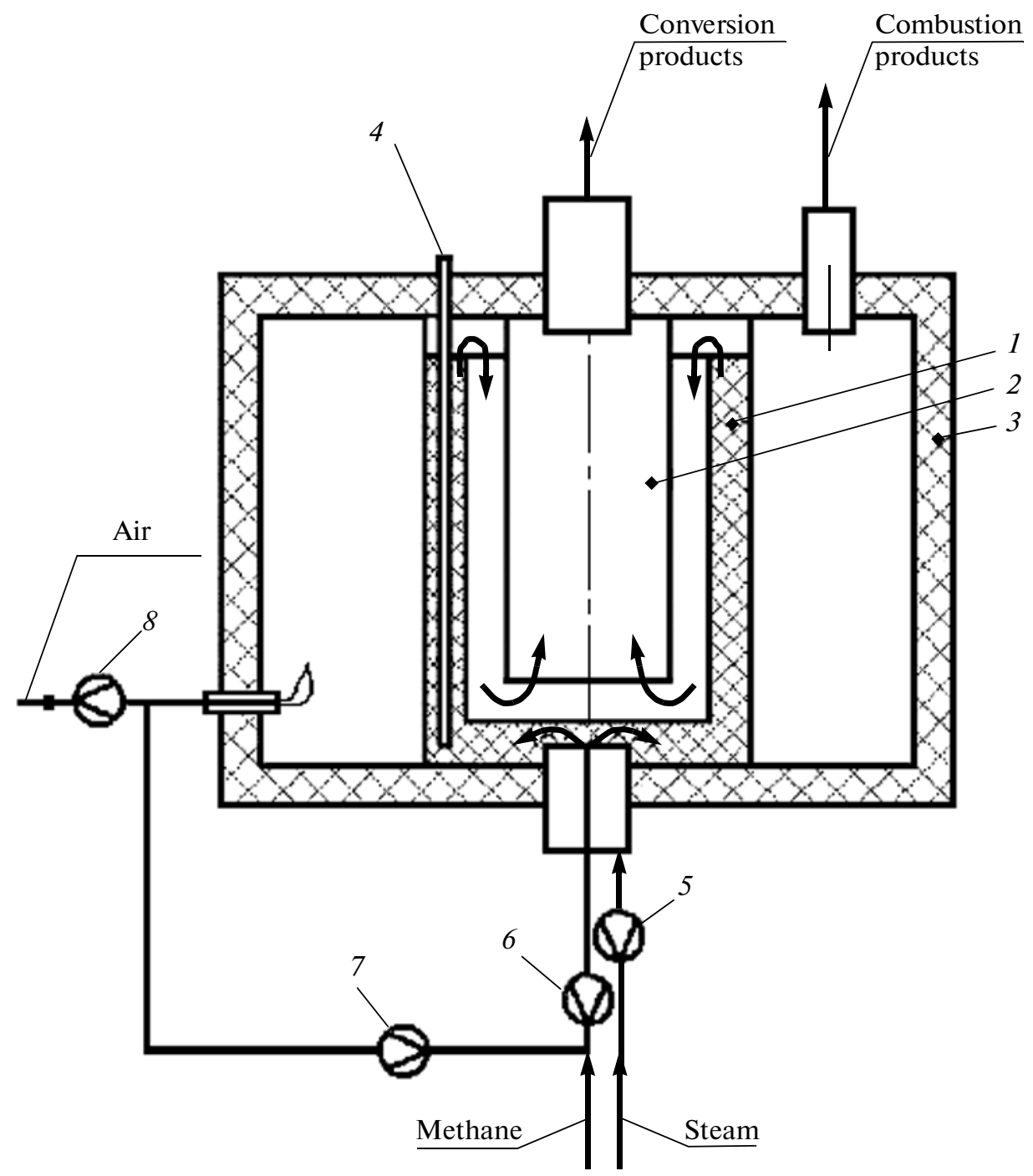

EN-60G endothermic reactor with a gas-heated retort filled with a catalyst: (1) retort with a catalyst, (2) recuperator, (3) thermal insulation, (4) tube for measuring catalyst temperature, (5)-(8) rotameters. 
the retort. The temperature of $710^{\circ} \mathrm{C}$ was maintained in the bed at an average velocity of products $w=$ $1.6 \mathrm{~m} / \mathrm{s}$. Methane was fed at a flow rate of $7 \mathrm{~m}^{3} / \mathrm{h}$ $(7 / 22.4=0.324 \mathrm{kmol} / \mathrm{h})$ to conversion and $4 \mathrm{~m}^{3} / \mathrm{h}$ to retort heating. Steam with a temperature of $200^{\circ} \mathrm{C}$ was fed at a flow rate of $11.3 \mathrm{~kg} / \mathrm{h}(11.3 / 18=0.627 \mathrm{kmol} / \mathrm{h})$.

The flow rates of methane and steam were measured with standard rotameters and an orifice plug, respectively. The catalyst temperature was measured by an $\mathrm{X}-\mathrm{A}$ thermocouple displaced inside a thin-wall tube, which was sealed along its lower edge and placed inside an annular catalyst-filled channel with a width of $25 \mathrm{~mm}$ and an outer diameter of $250 \mathrm{~mm}$. The composition of products was determined on a chromatograph and given in Table 1.

The volumetric fraction of steam in conversion products was determined from the flow rates of steam $V_{\mathrm{H}_{2} \mathrm{O}}$, and conversion products $V_{c g}$ and the volumetric concentrations of carbon monoxide $r_{\mathrm{CO}}^{d g}$, and carbon dioxide $r_{\mathrm{CO}_{2}}^{d g}$ in a dry gas were calculated by the relationship $r_{\mathrm{H}_{2} \mathrm{O}}=V_{\mathrm{H}_{2} \mathrm{O}} / V_{c g}-2 r_{\mathrm{CO}_{2}}^{d g}-r_{\mathrm{CO}}^{d g}$, after which the concentrations of components in a dry gas were recalculated on a wet gas basis. The ratio $\mathrm{H}_{2} \mathrm{O}: \mathrm{CH}_{4}=2: 1$ was additionally controlled using the balance equation $V_{\mathrm{H}_{2} \mathrm{O}} / V_{\mathrm{CH}_{4}}=\left(r_{\mathrm{H}_{2} \mathrm{O}}+r_{\mathrm{CO}}+2 r_{\mathrm{CO}_{2}}\right) /\left(r_{\mathrm{CH}_{4}}+r_{\mathrm{CO}}+r_{\mathrm{CO}_{2}}\right)$. From $7 \mathrm{~m}^{3} / \mathrm{h}$ of methane, the reaction $0.3125 \mathrm{CH}_{4}+$ $0.627 \mathrm{H}_{2} \mathrm{O}=0.362 \mathrm{H}_{2} \mathrm{O}+0.2231 \mathrm{CO}+0.8615 \mathrm{H}_{2}+$ $0.0422 \mathrm{CO}_{2}+0.07 \mathrm{CH}_{4}$ produced $35 \mathrm{~m}^{3} / \mathrm{h}$ of conversion products. The coefficients in the reaction equation denote the molar flow rates of components, e.g., the flow rate of hydrogen at the outlet of the reactor is $35 \times 0.552 / 22.4=0.8615 \mathrm{kmol} / \mathrm{h}$.

The results of the comparison of experiment with the data calculated by Eqs. (6), (9), (12), (15), and (16) at $K_{1}=87.5 \times \exp (-7882 / T)\left(\mathrm{m}^{3} /\left(\mathrm{m}^{2} \mathrm{~s}\right)\right)$ on the aluminum/nickel catalyst [6] and $K_{2}=$ 3.6exp $(-6600 / T),\left(\mathrm{m}^{3} /\left(\mathrm{m}^{2} \mathrm{~s}\right)\right)$ [7] are given in Table 1 .

The comparison of the steam carbon monoxide conversion product concentrations that were obtained experimentally [8] on an iron/chromium catalyst and calculated by Eqs. (20)-(23) at a temperature of $350^{\circ} \mathrm{C}$ is given in Table 2 . The rate constants $K_{2}^{*}=$ $40 \exp (-6600 / T),\left(\mathrm{m}^{3} /\left(\mathrm{m}^{2} \mathrm{~s}\right)\right)$ and $K_{3}^{*}=K_{2}^{*} / K_{e q}$ on an iron/chromium catalyst [9] and the equilibrium gas shift reaction rate constant $K_{e q}$, whose temperaturedependent values were taken from [5], were used in the calculations.

After the separation of the steam carbon monoxide conversion products $\mathrm{CO}_{2}$ and $\mathrm{H}_{2}$ in an absorber, the outlet gas mixture calculated by the model [10] has the following composition (vol \%): $r_{\mathrm{H}_{2}}, 98 ; r_{\mathrm{CO}_{2}}, 2$; the composition at the outlet from a desorber is the following (vol \%): $r_{\mathrm{CO}_{2}}, 99.4 ; r_{\mathrm{CO}}, 0.1, r_{\mathrm{CO}_{2}}, 0.5$ for monoethanolamine used as an absorbent [11].

\section{CONCLUSIONS}

In the present work, models allowing us to calculate the full range of product concentrations depending on the temperature and the capacity of reactors have been proposed for the two stages of the synthesis of hydrogen from methane, namely, the model for the first stage of steam methane reforming in a reactor with an aluminum/nickel catalyst at a ratio $\mathrm{H}_{2} \mathrm{O}: \mathrm{CH}_{4}=2: 1$ and the model for the stage of steam carbon monoxide conversion in the second reactor with an iron/chromium catalyst. The results of calculations are in satisfactory agreement with the experimental data obtained on an EN-60G industrial endothermic generator with a gas-heated retort and the experimental steam $\mathrm{CO}$ conversion data of the other authors. After the separation of $\mathrm{CO}_{2}$ from $\mathrm{H}_{2}$ in an absorption unit, the gas contains $98 \mathrm{vol} \%$ of $\mathrm{H}_{2}$ and $2 \mathrm{vol} \%$ of $\mathrm{CO}_{2}$.

\section{NOTATION}

$K_{1}$-rate constant for the reaction between $\mathrm{CH}_{4}$ and steam on an aluminum/nickel catalyst, $\mathrm{m}^{3} /\left(\mathrm{m}^{2} \mathrm{~s}\right)$;

$K_{2}, K_{2}^{*}$-rate constants for the reaction between carbon monoxide and steam on aluminum/nickel and iron/chromium catalysts, respectively, $\mathrm{m}^{3} /\left(\mathrm{m}^{2} \mathrm{~s}\right)$;

$K_{3}, K_{3}^{*}$-rate constants for the reaction between carbon dioxide and hydrogen on aluminum/nickel and iron/chromium catalysts, respectively, $\mathrm{m}^{3} /\left(\mathrm{m}^{2} \mathrm{~s}\right)$;

$K_{e q}$-equilibrium gas shift reaction rate constant, $\mathrm{m}^{3} /\left(\mathrm{m}^{2} \mathrm{~s}\right)$

$r, r^{d g}$-component concentration and component concentration in a dry gas, $\mathrm{m}^{3} / \mathrm{m}^{3}$;

$S$-specific surface area of a catalyst, $\mathrm{m}^{2} / \mathrm{m}^{3}$;

$T$-temperature, ${ }^{\circ} \mathrm{C}$;

$w_{z}, w_{0}, w$-conversion product velocity along the height $z$, at the outlet of a reactor, and average over the catalyst height on an empty cross section basis, respectively, at operational parameters, $\mathrm{m} / \mathrm{s}$;

$z$-vertical height coordinate along the catalyst bed, $\mathrm{m}$;

$\varepsilon$-catalyst porosity.

\section{SUBSCRIPTS AND SUPERSCRIPTS}

$c g$ - conversion products;

$d g$ - dry gas;

$e q$-equilibrium.

\section{REFERENCES}

1. Tiemersma, T.P., Chaudhari, A.S., Gallucci, F., et al., Integrated autothermal oxidative coupling and steam reforming of methane. Part 1: Design of dual-function catalyst particle, Chem. Eng. Sci., 2012, vol. 82, p. 200.

2. Dubinin, A.M., Kagarmanov, G.R., and Fink, A.V., Energetic effectiveness of some hydrogen production 
methods, Izv. Vyssh. Uchebn. Zaved., Khim. Tekhnol., 2009, vol. 52, p. 54.

3. Pisarenko, E.V. and Pisarenko, V.N., Power- and resource-saving process for producing syngas from natural gas in methanol production, Theor. Found. Chem. Eng., 2011, vol. 45, p. 349.

4. Fernandez, J.R., Abanades, J.C., and Murillo, R., Modeling of sorption enhanced steam methane reforming in an adiabatic fixed bed reactor, Chem. Eng. Sci., 2012, vol. 84, p. 1.

5. Zhorov, Yu.M., Termodinamika khimicheskikh protsessov (neftekhimicheskii sintez, pererabotka nefti, uglya i prirodnogo gaza) (Thermodynamics of Chemical Processes (Petrochemical Synthesis and Petroleum, Coal and Natural Gas Processing), Moscow: Khimiya, 1985.

6. Bodrov, I.M., Kinetics of the reaction between methane and water vapor catalyzed by nickel on a porous support, Kinet. Katal., 1967, vol. 8, p. 821.

7. Dubinin, A.M., Kagarmanov, G.R., and Fink, A.V., Modeling of methane steam reforming, Izv. Vysh.
Uchebn. Zaved., Problemy Energetiki, 2009, vol. 52, p. 54.

8. Falbe, J., Chemierohstoffe aus Kohle, Stuttgart: Thieme, 1977.

9. Estrin, B.M., Proizvodstvo i primenenie kontroliruemykh atmosfer (pri termicheskoi obrabotke stali) (Production and Application of Controllable Atmospheres in Steel Heat Treatment), Moscow: Metallurgiya, 1973.

10. Laptev, A.G., Modeli pogranichnogo sloya $i$ raschet teploobmennykh protsessov, (Boundary Layer Models and Heat Transfer Calculations), Kazan: Kazan. Univ., 2007.

11. Leibush, A.G., Proizvodstvo tekhnologicheskogo gaza dlya sinteza ammiaka i metanola iz uglevodorodnykh gazov (Production of the Process Gas for Ammonia and Methanol Synthesis from Gaseous Hydrocarbons), Moscow: Khimiya, 1971.

Translated by E. Glushachenkova 